\title{
Multiscale variation in the functional composition of stream macroinvertebrate communities in low-order mountain streams
}

\author{
Luz Boyero
}

Museo Nacional de Ciencias Naturales (CSIC), José Gutiérrez Abascal 2, 28006 Madrid, Spain

Present address: School of Tropical Biology, James Cook University, Townsville, Qld 4811, Australia

E-mail: luz.boyero@jcu.edu.au

\begin{abstract}
Although it has been shown that the structure and taxonomic composition of macroinvertebrate communities vary depending on multiple spatial scales, multi-scale variation of community functional composition has not been examined; despite the fundamental role of this functional composition for many ecosystem processes. In this study, functional composition of macroinvertebrate communities, in terms of the relative abundances of the different functional feeding groups, was examined in two streams in Central Spain. Differences in functional composition were found at every scale, but mostly at the segment, riffle, and sample scales, as previously observed for other community characteristics. This study highlights the necessity of multiscale designs for the study of ecological patterns and processes in streams.
\end{abstract}

Keywords: Functional feeding groups; spatial scales; macroinvertebrates.

\section{RESUMEN}

Aunque se ha demostrado que la estructura y la composición taxonómica de las comunidades de macroinvertebrados varían según la escala espacial, no existe ningún estudio a múltiples escalas sobre la composición funcional de las comunidades, a pesar del papel fundamental de esta composición funcional en muchos procesos del ecosistema. En este estudio se examina la composición funcional de las comunidades de macroinvertebrados, en términos de la abundancia relativa de los diferentes grupos funcionales, en dos rios del centro de España. Se encontraron diferencias en la composición funcional a todas las escalas consideradas, pero la mayor variación ocurrió a las escalas de segmento, rápido y muestra, de forma similar a otras características de la comunidad estudiadas previamente. Este estudio enfatiza la necesidad de realizar diseños a múltiples escalas para comprender los patrones y procesos ecológicos que tienen lugar en los sistemas fluviales.

Palabras clave: Grupos tróficos funcionales; escalas espaciales; macroinvertebrados.

\section{INTRODUCTION}

Macroinvertebrates play fundamental roles in stream ecosystems, being consumers at intermediate trophic levels and thus serving as channels by which bottom-up and top-down forces are transmitted (Wallace \& Webster, 1996). Different food sources utilized by macroinvertebrates include: the epilithic layer that grows on the surfaces of substrates (consumed by scrapers); the coarse detritus, composed mainly by leaves falling down from riparian vegetation (consumed by shredders); the fine detritus, either deposited on the substrate (consumed by gatherers) or suspended in the water column (consumed by filterers); and finally, live animals (consumed by predators).

The functional composition of macroinvertebrate communities, quantified as the proportions of these different functional feeding groups (FFGs), has important implications for ecosystem functioning (Minshall et al., 1983). Although the concept of FFG has been largely questioned given that most macroinvertebrates show a high plasticity in the use of food resources (Dangles, 2002), the classification of 
macroinvertebrates in FFGs is still highly useful to describe communities functionally, especially to compare stream sites of different size, riparian vegetation, physicochemical characteristics, etc. This is evidenced in that the River Continuum Concept (RCC), which predicts changes in community functional composition with stream size (Vannote et al., 1980), still remains as the main paradigm in stream ecology.

Ecological patterns and processes in streams have been shown to vary at multiple spatial scales, between and within streams (e.g. Boyero \& Bailey, 2001; Boyero \& Bosch, 2002, 2004; Boyero, 2003). However, there have been very few attempts of studying how the functional composition of macroinvertebrate communities changes with spatial scale. The aim of this study was to compare the functional composition of macroinvertebrate communities (in terms of relative abundances of the different FFGs) at multiple spatial scales, from the basin to the sample, in two streams in Central Spain.

\section{METHODS}

This study was conducted in Peñalara and Barranca streams, both mountain streams located in the Sierra de Guadarrama, Madrid, Central Spain. Riparian vegetation at Peñalara basin is typical of alpine meadows above $1850 \mathrm{~m}$, with sparse Cytisus scoparius and Juniperus communis, and Pinus sylvestris below $1900 \mathrm{~m}$. At Barranca basin, riparian vegetation consists of Pinus sylvestris above $1500 \mathrm{~m}$. The bioclimatic region is the Mediterranean, with a mean annual temperature of $4-13^{\circ} \mathrm{C}$ and annual precipitation of $600-1000 \mathrm{~mm}$, but the altitude of these mountain streams makes them more similar to temperate streams. The geological nature of the area, predominantly composed of Paleozoic igneous and metamorphic bedrock, makes the water slightly acid, with $\mathrm{pH}$ about 6 . The substrate of Peñalara and Barranca streams is dominated by cobbles $(54-256 \mathrm{~mm})$, followed by gravel (2-54 $\mathrm{mm})$, sand $(<2 \mathrm{~mm})$ and boulders $(>256 \mathrm{~mm})$, which are often covered by moss.
Macroinvertebrates were sampled from riffle habitats at an altitude of 1583-2034 $\mathrm{m}$ above sea level in the summer of 2000 (from middle June to late July). The 18 studied riffles had a length, mean channel width, water depth, current velocity and water temperature that varied between 4.3-19.1 m, 0.4-4.9 m, 4.3-12.0 cm, 6.3-33.3 $\mathrm{cm} \mathrm{s}^{-1}$ and $11.0-17.7^{\circ} \mathrm{C}$, respectively.

Samples were taken in a nested design, with five successive spatial scales: basin (scale of $10^{3} \mathrm{~m}$ ), segment (scale of $10^{2} \mathrm{~m}$ ), riffle (scale of $10^{1} \mathrm{~m}$ ), section (scale of $10^{0} \mathrm{~m}$ ) and sample (scale of $10^{-1} \mathrm{~m}$ ). Three segments at each basin, three riffles at each segment, three sections at each riffle, and three samples at each section were randomly selected. This design allowed estimating the components of variance associated with each of the five successive spatial scales. Samples were taken with a modified Surber sampler of 15 x $15 \mathrm{~cm}$ (see Boyero, 2003, for more details on sampling methods) and preserved in $4 \%$ formaldehyde. Macroinvertebrates were sorted, identified, and allocated to a FFG (scrapers, shredders, gatherers, filterers and predators; sensu Wallace \& Webster, 1996), based on Tachet et al. (1987). Taxonomic resolution was species or genus when possible (Ephemeroptera, Plecoptera, Coleoptera, Heteroptera, Megaloptera, Hydracarina, and some Trichoptera and Diptera), otherwise family (some Trichoptera and Diptera) or lowest taxonomic level (Odonata, Tricladida, Hirudinea, Oligochaeta and Gastropoda). Although identification to species level is desirable, Gayraud et al. (2003) showed that functional descriptions of macroinvertebrate communities (including allocation into FFGs) at the genus and family levels were similar to those derived at the species level, reflecting a high taxonomic constraint in the evolution and the actual organization of biological traits in stream macroinvertebrates. Thus, identifications at the genus or family levels allow realistic functional description of lotic macroinvertebrate communities (Dolédec et al., 2000; Gayraud et al., 2003).

The variables considered were the relative abundances of the different FFGs, that is, the percentage of individuals of each FFG in 
the sample, which were $\arcsin (\sqrt{ } \mathrm{x})$ transformed to attain the assumptions of parametric analysis. After transformation, the variables were tested for normality using the Kolmogorov-Smirnov test, and for homocedasticity using the Bartlett test. A nested MANOVA was used to test for differences in the relative abundances of the five FFGs between streams, segments within streams, riffles within segments, and sections within riffles. The variance components (i.e. the percentage of variation accounted by each spatial scale) were considered, given that the high differences in number of replicates among scales could lead to an erroneous interpretation of results based only on probability values. The sample scale constitutes the error term of the analysis, so only the percentage of variance accounted by this scale (but not the probability value) can be calculated. Given that the MANOVA was significant, a protected ANOVA was performed for each variable (that is, for the relative abundance of each FFG), to analyze the patterns of variation of each FFG independently. The analyses were performed with the GLM module of Statistica 5.5, StatSoft Inc.

\section{RESULTS}

A total of 82 macroinvertebrate taxa were collected and identified, from the insect orders Ephemeroptera, Plecoptera, Trichoptera, Diptera, Coleoptera, Heteroptera, Odonata, and Megaloptera, and the non-insect groups Hydracarina, Tricladida, Hirudinea, Oligochaeta and Gastropoda (a list of all taxa can be found in Boyero, 2003). The most abundant FFG was the gatherers (average of $64 \%$ of individuals in the samples), followed by shredders (14\%), predators $(11 \%)$, scrapers $(9 \%)$, and filterers (3\%).

The nested MANOVA was highly significant for all the spatial scales: basin (Wilks' $\lambda=0.14$, $\mathrm{F}_{5,50}=59.89, \quad \mathrm{p}<0.0001$ ), segment (Wilks' $\lambda=0.07, \mathrm{~F}_{20,167}=10.07, \mathrm{p}<0.0001$ ), riffle (Wilks' $\lambda=0.03, \mathrm{~F}_{60,238}=4.73, \mathrm{p}<0.0001$ ), and section (Wilks' $\lambda=0.03, \mathrm{~F}_{180,253}=1.42, \mathrm{p}=0.0049$ ). When each FFG was analyzed separately by an inde- pendent ANOVA, different patterns of variation at multiple scales appeared (Table 1, Fig. 1), although there were also some patterns common to all FFGs: variation at riffle scale was always

Table 1. Variability in the relative abundance of each macroinvertebrate FFG as shown by nested ANOVAs including the spatial scales of basin, segment (nested within the basin), riffle (nested within the segment), section (nested within the riffle), and sample (which constitutes the error term of the analysis). For each spatial scale, the degrees of freedom, mean square, F statistic, level of significance, and percentage of variance accounted by each spatial scale, are shown. Variabilidad en la abundancia relativa de cada grupo funcional de macroinvertebrados FFG según se muestra mediante ANOVAs anidados que incluyen las escalas espaciales de la cuenca, segmentos (agrupados por cuenca), tramos (agrupados por segmento), secciones (agrupadas por tramos), y muestras (que constituyen el término de error del análisis). Para cada escala espacial se muestran los grados de libertad, el cuadrado medio, el estadístico $F$, el nivel de significación, y el tanto por ciento de la varianza explicada.

\begin{tabular}{|c|c|c|c|c|c|}
\hline & df & MS & $\mathbf{F}$ & $\mathbf{p}$ & $\%$ Var \\
\hline \multicolumn{6}{|l|}{ Scrapers } \\
\hline Basin & 1 & 1.34 & 10.68 & 0.0309 & 8 \\
\hline Segment & 4 & 0.13 & 1.56 & 0.2466 & 0 \\
\hline Riffle & 12 & 0.08 & 7.53 & $<0.0001$ & 35 \\
\hline Section & 36 & 0.01 & 0.83 & 0.7389 & 0 \\
\hline Sample / error & 108 & 0.01 & & & 57 \\
\hline \multicolumn{6}{|l|}{ Shredders } \\
\hline Basin & 1 & 0.44 & 2.60 & 0.1821 & 0 \\
\hline Segment & 4 & 0.17 & 4.87 & 0.0144 & 17 \\
\hline Riffle & 12 & 0.03 & 2.28 & 0.0278 & 3 \\
\hline Section & 36 & 0.02 & 0.68 & 0.9066 & 0 \\
\hline Sample / error & 108 & 0.02 & & & 80 \\
\hline \multicolumn{6}{|l|}{ Collectors } \\
\hline Basin & 1 & 1.43 & 2.92 & 0.1624 & 0 \\
\hline Segment & 4 & 0.49 & 9.16 & 0.0012 & 35 \\
\hline Riffle & 12 & 0.05 & 2.60 & 0.0133 & 8 \\
\hline Section & 36 & 0.02 & 0.79 & 0.7902 & 0 \\
\hline Sample / error & 108 & 0.03 & & & 57 \\
\hline \multicolumn{6}{|l|}{ Filterers } \\
\hline Basin & 1 & 0.21 & 4.79 & 0.0938 & 0 \\
\hline Segment & 4 & 0.04 & 1.01 & 0.4383 & 0 \\
\hline Riffle & 12 & 0.04 & 2.38 & 0.0219 & 17 \\
\hline Section & 36 & 0.02 & 1.56 & 0.0409 & 13 \\
\hline Sample / error & 108 & 0.01 & & & 70 \\
\hline \multicolumn{6}{|l|}{ Predators } \\
\hline Basin & 1 & 0.05 & 0.30 & 0.6132 & 0 \\
\hline Segment & 4 & 0.17 & 4.41 & 0.0201 & 21 \\
\hline Riffle & 12 & 0.04 & 2.56 & 0.0145 & 11 \\
\hline Section & 36 & 0.02 & 0.97 & 0.5255 & 0 \\
\hline Sample / error & 108 & 0.02 & & & 68 \\
\hline
\end{tabular}



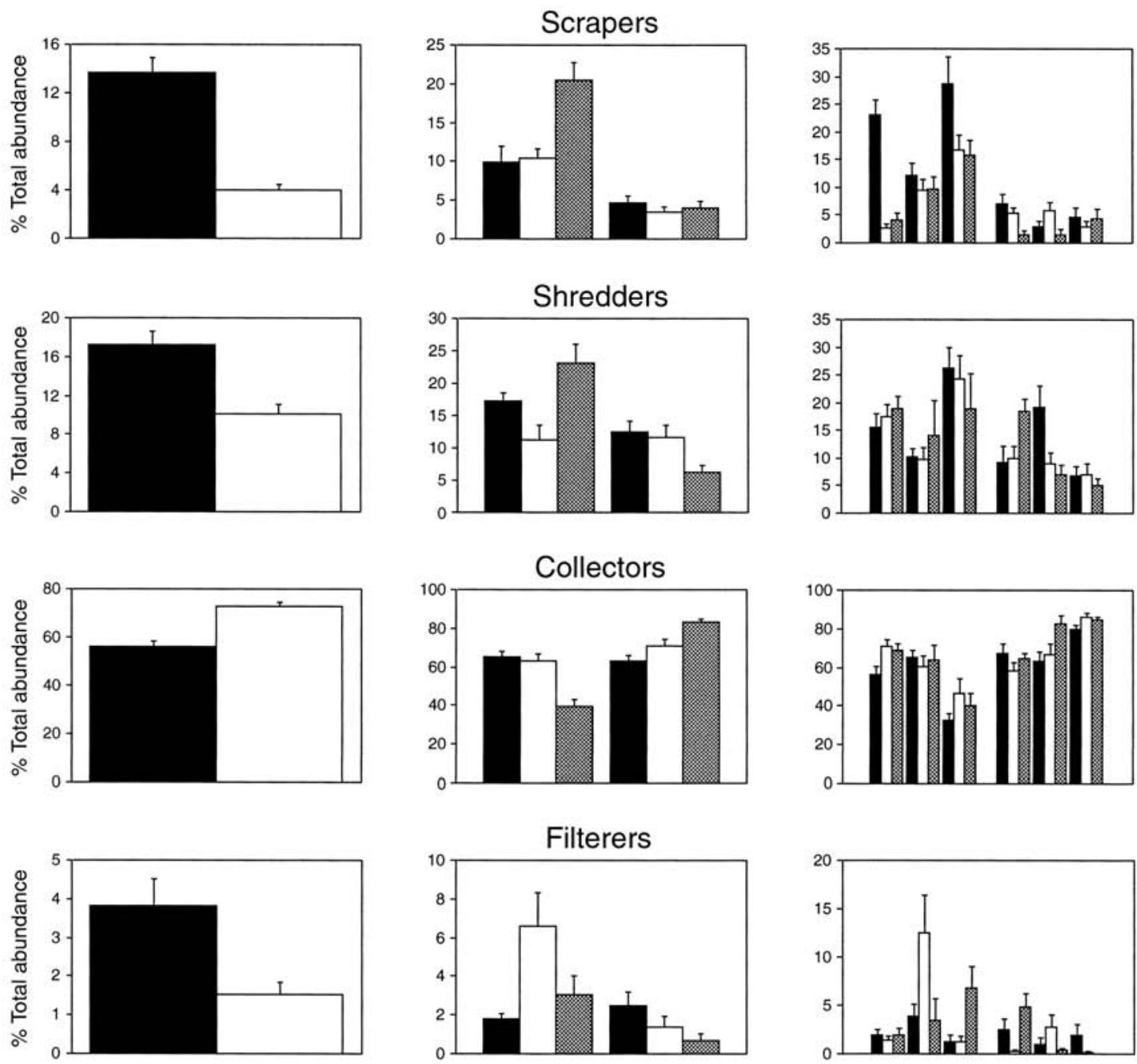

Filterers
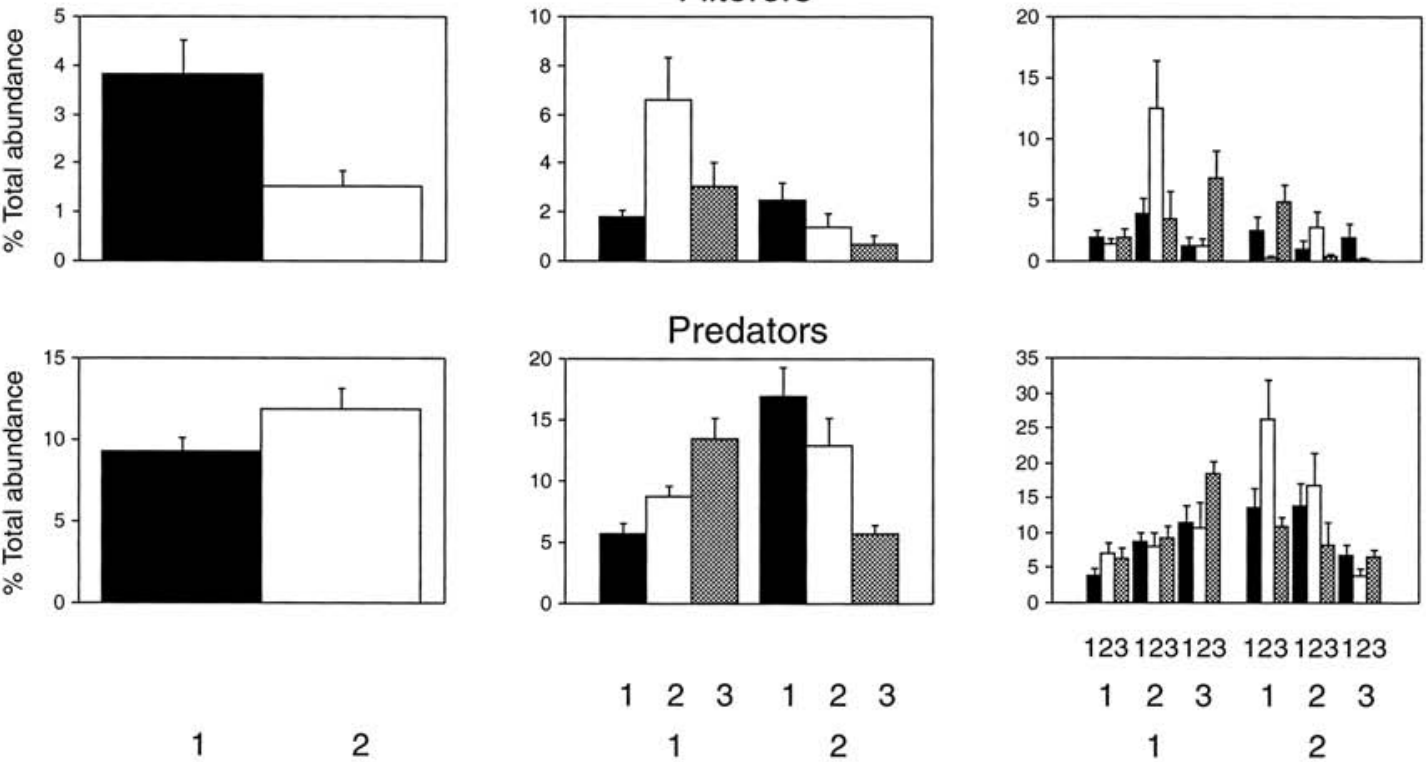

Basin scale

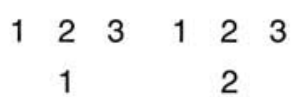

Segment scale

\section{Riffle scale}

Figure 1. Percentage of total abundance represented by each FFG, at basin, segment, and riffle scales. Basin 1 is the Peñalara stream; basin 2 is the Barranca stream. Tanto por ciento de la abundancia total representada por cada FFG, a escala de cuenca, segmento y tramo. La cuenca 1 es el arroyo Peñalara, la cuenca 2 es el arroyo Barranca. 
significant, and variation at sample scale was always high (57-80\% of total variance). Variation was also high at basin scale for scrapers, at segment scale for shredders, gatherers and predators, and at section scale for filterers.

\section{DISCUSSION}

The variation of the different FFGs at different spatial scales can be explained by their mode of search for their food resources, together with the environmental variability at those scales. For example, variation of shredders, gatherers and predators at segment and riffle scales can be related to their active search for food resources (leaf patches, deposited fine detritus patches, and prey items, respectively). These animals are constantly moving, and the distances traveled depend on how sparse are their food sources distributed. When food sources are more heterogeneous, individuals can travel long distances until they find a suitable patch.

Scrapers were the only group that varied at basin scale, being much more abundant at Peñalara than Barranca stream (14\% versus $4 \%$ of the total number of individuals). This can be due to the fact that Peñalara stream receives much more solar energy, given that riparian vegetation is scarce, so periphyton is more abundant in this stream. Filterers varied at a small scale (section), and this could be related to the distribution of water velocity, which also varies at small scales in these streams (Boyero, 2003). Filterers feed on suspended fine particulate organic matter, which is transported by the current, and thus these organisms usually select areas of fast current, which provides more organic matter in a shorter period of time (e.g. Georgian \& Thorp, 1992).

The general characteristics of macroinvertebrate communities (abundance, taxon richness, evenness) and their taxonomic composition have also been demonstrated to change with spatial scale (Downes et al., 1993; Townsend et al., 1997; Boyero \& Bailey, 2001; Li et al., 2001; Boyero, 2003). Those studies showed that multiscale studies are essential for the identification of scales at which ecological patterns can be detected in streams. Moreover, the dynamics of macroinvertebrate communities are also dependent on spatial scale, as shown for macroinvertebrate drift (Boyero \& Bosch, 2002) or for the process of stone recolonization (Boyero \& Bosch, 2004). The present study illustrates that studies at multiple spatial scales are also essential for relating patterns and processes, given that the functional composition of macroinvertebrate communities is directly related to stream processes. The relative abundances of the different FFGs are main characteristics of macroinvertebrate communities with important implications at ecosystem level (Ramírez \& Pringle, 1998), and thus directly relate community structure with ecosystem functioning.

The River Continuum Concept (RCC) predicts that community functional composition changes with stream size, with shredders and gatherers being dominant in low-size forested streams, scrapers and gatherers in medium-sized streams, and gatherers and filterers in larger streams (Vannote et al., 1980). However, this study shows that variation in functional composition also occurs at much smaller scales, at least within low-order streams similar to the streams studied here, where functional composition can vary at segment, riffle, and within-riffle scales. This implies the convenience of developing multiscale designs for the study of organic matter processing and, consequently, of many ecosystem processes, in streams. For example, Royer \& Minshall (2003) showed that leaf processing in streams is scale-dependent and that factors controlling processing rates largely depend on the spatial scale of study. They presented a hierarchical framework relating constraints on leaf processing to specific spatial scales, which allowed the development of scale-specific predictions of how environmental changes could affect leaf processing. It would be desirable to develop similar multi-scale frameworks to study the different ecosystem processes, and the distribution patterns of the organisms involved in those processes, in order to understand the relationships 
between community structure and ecosystem functioning in streams.

\section{ACKNOWLEDGEMENTS}

Richard G. Pearson, Jaime Bosch and two anonymous referees provided useful comments on an earlier version of the manuscript. The author was supported by a postdoctoral grant from the Secretaría de Estado de Educación y Universidades (MECD, Spain) co-financed by the European Social Fund.

\section{REFERENCES}

BOYERO, L. 2003. Multiscale patterns of spatial variation of stream macroinvertebrate communities. Ecol. Res., 18: 365-379

BOYERO, L. \& R. C. BAILEY. 2001. Organization of macroinvertebrate communities at a hierarchy of spatial scales in a tropical stream. Hydrobiologia, 464: 219-225

BOYERO, L. \& J. BOSCH. 2002. Spatial and temporal variation of macroinvertebrate drift in two Neotropical streams. Biotropica, 34: 567-574

BOYERO, L. \& J. BOSCH. 2004. Multiscale spatial variation of stone recolonization by macroinvertebrates in a Costa Rican stream. J. Trop. Ecol., 20: 85-95.

DOLÉDEC, S., J. M. OLIVIER \& B. STATZNER. 2000. Accurate description of the abundance of taxa and their biological traits in stream invertebrate communities: effects of taxonomic and spatial resolution. Arch. Hydrobiol., 148: 25-43.

DOWNES, B. J., P. S. LAKE \& E. S. G. SCHREIBER. 1993. Spatial variation in the distribution of stream invertebrates: implications of patchiness for models of community organization. Freshwat. Biol., 30: 119-132.

GEORGIAN, T. \& J. H. THORP. 1992. Effects of microhabitat selection on feeding rates of netspinning caddisfly larvae. Ecology, 73: 229-240.

LI, J., A. HERLIHY, W. GERTH, P. KAUFFMAN, S. GREGORY, S. URQUHART \& D. P. LARSEN. 2001. Variability in stream macroinvertebrates at multiple spatial scales. Freshwat. Biol., 46: 87-97

MINSHALL, G. W., R. C. PETERSEN, K. W. CUMMINS, T. L. BOTT, J. R. SEDELL, C. E. CUSHING \& R. L. VANNOTTE. 1983. Interbiome comparison of stream ecosystem dynamics. Ecol. Monogr., 53: 1-15.

RAMÍREZ, A. \& C. M. PRINGLE. 1998. Invertebrate drift and benthic community dynamics in a lowland Neotropical stream, Costa Rica. Hydrobiologia, 386: 19-26.

ROYER, T. V. \& W.G. MINSHALL. 2003. Control on leaf processing in streams from spatial-scaling and hierarchical perspectives. J. N. Amer. Benthol. Soc. 22: 352-358.

TACHET, H. M., M. BOURNAUD et P. RICHOUX. 1987. Introduction à l'étude des macroinvertébrés des eaux douces (systé matique élémentaire et aperçu écologique). Association Française de Limnologie/Université Lyon, Lyon, France. 155 pp.

TOWNSEND, C. R., C. J. ARBUCKLE, T. A. CROWL \& M. R. SCARSBROOK. 1997. The relationship between land use and physicochemistry, food resources and macroinvertebrate communities in tributaries of the Taieri River, New Zealand: a hierarchically scaled approach. Freshwat. Biol., 37: 177-191.

VANNOTTE, R. L., G. W. MINSHALL, K. W. CUMMINS, J. R. SEDELL \& C. E. CUSHING. 1980. The river continuum concept. Can. J. Fish. Aquat. Sci., 37: 130-137.

WALLACE, J. B. \& J. R. WEBSTER. 1996. The role of macroinvertebrates in stream ecosystem function. Annu. Rev. Entomol., 41: 115-139. 